\section{Research Square}

\title{
Antibody-guided Chromatin Tagmentation for Two or More Factors (ACT2-seq)
}

Benjamin Carter ( $\nabla$ benjamin.carter@nih.gov )

NHLBI https://orcid.org/0000-0001-6530-9568

\section{Wai Lim Ku}

NHLBI

\section{Keji Zhao}

NHLBI

\section{Method Article}

Keywords: Co-occupancy, Co-enrichment, ACT-seq, tagmentation, epigenetic marks

Posted Date: November 16th, 2021

DOl: https://doi.org/10.21203/rs.3.pex-1695/v1

License: (1) This work is licensed under a Creative Commons Attribution 4.0 International License. Read Full License 


\section{Abstract}

This protocol details the reagents and steps required to perform antibody-guided chromatin tagmentation for two or more factors (ACT2-seq, ACT2). Like its predecessor ACT-seq, ACT2 uses a fusion of protein A and Tn5 transposase to bind and profile epigenetic marks across the genome. ACT2 builds on the capabilities of ACT-seq by directly and concurrently profiling co-occupancy of epigenetic marks, which previously required laborious, expensive, and technically challenging approaches involving fluorescence, magnetic beads, or single-cell methods. ACT2 requires only standard pipetting and centrifugation techniques and can be completed in less than a single day of bench work.

\section{Introduction}

\section{Reagents}

Recombinant PA-Tnp protein (see Appendix A in supplemental file, or use commercial enzyme)

Oligonucleotide complex adapters (see Appendix B in supplemental file for design)

Library preparation adapters (see Appendix B in supplemental file for design)

\section{X Complex Buffer (CB)}

$0.1 \mathrm{M}$ Tris $\mathrm{pH} 8.0$

$0.3 \mathrm{M} \mathrm{NaCl}$

$0.1 \%$ Triton $\mathrm{X}-100$

$25 \%$ Glycerol
For $50 \mathrm{~mL}:$

$5 \mathrm{~mL}$ of $1 \mathrm{M}$ Tris $\mathrm{pH} 8.0$

$3 \mathrm{~mL}$ of $5 \mathrm{M} \mathrm{NaCl}$

50 uL of $100 \%$ Triton X-100

$12.5 \mathrm{~mL}$ of $100 \%$ Glycerol

Add protease inhibitors to a $500 \mathrm{~mL}$ aliquot immediately before use.

Store at room temperature.

\section{Wash Buffer}

$50 \mathrm{mM}$ Tris $\mathrm{pH} 8.0$

$150 \mathrm{mM} \mathrm{NaCl}$

$0.05 \%$ Triton X-100
For $50 \mathrm{~mL}$ :

$2.5 \mathrm{~mL}$ of $1 \mathrm{M}$ Tris $\mathrm{pH} 8.0$

$1.5 \mathrm{~mL}$ of $5 \mathrm{M} \mathrm{NaCl}$

25 uL of $100 \%$ Triton X-100 
Store at room temperature.

\section{RIPA Buffer}

Prepare in $1 \mathrm{X}$ TE pH 7.5

$150 \mathrm{mM} \mathrm{NaCl}$

$0.2 \%$ SDS

$0.1 \%$ Na deoxycholate

$1 \%$ Triton X-100
For $10 \mathrm{~mL}$ :

$300 \mathrm{uL}$ of $5 \mathrm{M} \mathrm{NaCl}$

200 uL of $10 \%$ SDS

$10 \mathrm{mg}$ of solid Na deoxycholate

100 uL of $100 \%$ Triton X-100

Prepare fresh each time. Deoxycholate is light sensitive.

\section{Materials:}

Phusion ${ }^{\circledR}$ High-Fidelity PCR Master Mix with HF Buffer (NEB, cat. \#M0531S)

MinElute PCR Purification Kit (Qiagen cat. \#28004, or equivalent)

MinElute Gel Extraction Kit (Qiagen cat. \#28604, or equivalent)

\section{Equipment}

A centrifuge with a swinging-bucket rotor (as opposed to a fixed-angle rotor) is highly recommended for all spin steps. This allows the cells to accumulate at the bottom of the tube instead of smeared along the sides, preserving cell number during buffer removal steps.

\section{Procedure}

See Appendix A in the supplemental file for expression and purification of recombinant PA-Tnp.

See Appendix B in the supplemental file for instructions on preparing the annealed complex adapters. 


\section{Antibody-PA-Tnp Complex Formation (1 hour)}

1. For each PA-Tn5 complex adapter pair, mix the following in a microcentrifuge tube and incubate at room temp. for 10 min:

4.5 uL of $2 X \mathrm{CB}+\mathrm{PI}$

2 uL of 50 uM annealed complex adapter A

$2 \mathrm{uL}$ of $50 \mathrm{uM}$ annealed complex adapter B

$2.5 \mathrm{uL}$ of $1 \mathrm{ug} / \mathrm{uL}$ recombinant PA-Tn5 enzyme

2. Label a set of microcentrifuge tubes for each antibody/PA-Tn5 complex combination. To each of these tubes, add $1.5 \mathrm{uL}$ of the matching complex from step 1, 1.5 uL of $2 \mathrm{X} \mathrm{CB}+\mathrm{PI}$, and $1.5 \mathrm{uL}$ of the desired antibody. (Multiply these volumes for the number of replicates, if applicable.) Mix by pipetting and incubate at room temperature for $30 \mathrm{~min}$.

\section{Cell Permeabilization (30 min)}

See Appendix $C$ in the supplemental file for instructions on preparing crosslinked cells. If using frozen crosslinked cells, thaw a cell pellet equivalent to 1 million cells on ice and proceed immediately to step 4 below.

If starting with fewer than 1 million cells, scale the final volume used in step 7 appropriately.

3. Transfer 1 million cells to a clean $1.5 \mathrm{~mL}$ tube and centrifuge for $2 \mathrm{~min}$ at 500 * $\mathrm{g}$.

4. Remove the supernatant and suspend the pellet in $1 \mathrm{~mL}$ of freshly prepared RIPA Buffer. Incubate the tube at room $\mathrm{T}$ for 10 min to lyse the cells and decondense the chromatin.

Note: a swinging-bucket rotor is strongly recommended for the remaining centrifugations!

5. Spin down the cells at $850{ }^{*} \mathrm{~g}$ for $2 \mathrm{~min}$. Carefully remove the supernatant, leaving $\sim 50 \mathrm{uL}$ at the bottom to avoid loss of cells.

6. Suspend the cells in $1 \mathrm{~mL}$ of Wash Buffer. Repeat the centrifugation and carefully remove the supernatant down to $\sim 50 \mathrm{uL}$ 
7. Suspend the cells in $1 \mathrm{~mL}$ of Wash Buffer. If you started with fewer than $\sim 1$ million cells, make sure the final cell concentration is equivalent.

\section{Complex Binding and Tagmentation (2 hours)}

8. Label a $1.5 \mathrm{~mL}$ tube for each sample. Transfer a $50 \mathrm{uL}$ cell aliquot ( 50 thousand cells) into each tube. Add $4.5 \mathrm{uL}$ of the matched AB-Tnp complexes from step 2 for the first binding step. Mix each sample by pipetting gently. Incubate the samples at room temperature for $30 \mathrm{~min}$.

9. Add $1 \mathrm{~mL}$ of Wash Buffer to each tube. Rotate the tubes for $5 \mathrm{~min}$ at room temperature. Centrifuge the cells at $850{ }^{*} \mathrm{~g}$. Remove the supernatant, leaving $\sim 50 \mathrm{uL}$ at the bottom to avoid loss of cells.

10. Add $3 \mathrm{uL}$ of $50 \mathrm{uM}$ annealed blocking adapter to the sample and mix by pipetting. Incubate for 10 min at room temperature.

11. Add $4.5 \mathrm{uL}$ of the next $\mathrm{AB}-\mathrm{Tnp}$ complex to each sample and mix by pipetting gently. Incubate at room temperature for $30 \mathrm{~min}$.

12. If probing more than two marks per sample, repeat steps 9 through 11 for each remaining complex.

13. Add $500 \mathrm{uL}$ of Wash Buffer to each tube and rotate the tubes for $5 \mathrm{~min}$ at room temperature. Centrifuge the cells at $850 * \mathrm{~g}$ and remove the supernatant down to $\sim 50 \mathrm{uL}$.

\section{Repeat step 13 .}

15. Dilute the samples to $100 \mathrm{uL}$ with Wash Buffer using the volume markings on the sides of the tubes. Add $1.5 \mathrm{uL}$ of $1 \mathrm{M} \mathrm{MgCl}_{2}$ to each tube of cells and gently suspend the cells by pipetting. Incubate the cells at $37^{\circ} \mathrm{C}$ for $60 \mathrm{~min}$ to allow targeted tagmentation to occur.

Note: extending this reaction time is not recommended as it may increase the background signal at accessible chromatin regions due to nonspecific transposase activity.

\section{Sample Purification (1.5 hours)}

16. Stop the reactions by adding $8 \mathrm{uL}$ of $0.5 \mathrm{M}$ EDTA. Vortex thoroughly to mix. Incubate samples at 80 ${ }^{\circ} \mathrm{C}$ for $5 \mathrm{~min}$.

17. Add $2 \mathrm{uL}$ of $10 \%$ SDS and $1 \mathrm{uL}$ of $20 \mathrm{mg} / \mathrm{mL}$ Proteinase $\mathrm{K}$. Incubate at $55^{\circ} \mathrm{C}$ for $60 \mathrm{~min}$.

18. Purify the DNA using a MinElute PCR Purification kit (or equivalent) and an elution volume of $20 \mathrm{uL}$. 
19. Store the purified samples at $-20^{\circ} \mathrm{C}$ or $-80^{\circ} \mathrm{C}$ or proceed to the following section.

\section{Library Preparation (1 hour)}

Note: the library PCR adapters are not the same as the complex adapters used in step 1! Use barcoded Illumina NextEra PCR primers or equivalent.

20. Transfer each $20 \mathrm{uL}$ sample to a PCR tube. To each sample, add $0.5 \mathrm{uL}$ of $50 \mathrm{uM} \mathrm{PCR}$ adapter \#1, $0.5 \mathrm{uL}$ of $50 \mathrm{uM}$ PCR adapter \#2, and $20 \mathrm{uL}$ of 2X NEB Phusion HF Master Mix. Mix by pipetting and amplify using the following program:

$72{ }^{\circ} \mathrm{C}$ for $5 \mathrm{~min}$

$98^{\circ} \mathrm{C}$ for $10 \mathrm{~s}$

$65^{\circ} \mathrm{C}$ for $30 \mathrm{~s} \quad \mid 15$ to 17 cycles

$72{ }^{\circ} \mathrm{C}$ for $15 \mathrm{~s}$

$72{ }^{\circ} \mathrm{C}$ for $5 \mathrm{~min}$

21. Visualize the PCR products using gel electrophoresis (e.g. on a $2 \%$ E-gel run for $20 \mathrm{~min}$ ). Visible smears and bands above $\sim 250$ bp indicate a detectable signal.

22. Excise gel slices corresponding to DNA fragment sizes between $\sim 250$ to $800 \mathrm{bp}$. Purify the PCR products using a MinElute Gel Purification Kit (or equivalent). The DNA libraries are ready for quantification, multiplexing, and sequencing.

\section{Troubleshooting}

\section{Problem: no visible band/smear above $\sim 250$ bp on the DNA gel after PCR.}

This indicates that the protocol did not work correctly, but does not give any information as to what step was responsible. If you encounter this issue, we recommend running a positive-control sample generated using either H3K4me3 or H3K27ac alongside your experimental samples. If there is no visible signal in the positive control lane, it indicates an issue with the cells or experimental steps. If you aren't already, definitely consider trying a swinging-bucket rotor to maintain cell number throughout the experiment.

Problem: only certain antibodies fail to produce visible signals on the DNA gel. 
This problem commonly arises in all techniques for probing epigenetic marks. Some epitopes require different cell fixation conditions to detect. We recommend varying the stringency of crosslinking and observing whether any signal appears on the DNA gel for your antibody. For example, in our hands $0.5 \%$ FA for 10 min works better for many transcription factors than does $1 \%$ FA for 10 min.

\section{Problem: after purifying the libraries from the DNA gel, the concentration is too low to sequence.}

If your Qubit measurements are too low for sequencing, we suggest running two or more library gel fragments (PCR products) through the same column during purification. Combining matching samples/PCR products in this manner can help obtain sequence-able amounts of otherwise dilute products.

\section{Supplementary Files}

This is a list of supplementary files associated with this preprint. Click to download.

- ACT2Protocol.docx 